DOI: https://doi.org/10.24127/ajpm.v9i4.3133

\title{
EFEKTIVITAS PEMBELAJARAN DARING BERBASIS MASALAH BERBANTUAN GEOGEBRA TERHADAP KEMAMPUAN PENALARAN MATEMATIS DI ERA COVID-19
}

\author{
Asep Ikin Sugandi ${ }^{*}$, Martin Bernard ${ }^{2}$, Linda $^{3}$ \\ $1^{*, 2,3}$ IKIP Siliwangi, Cimahi, Jawa Barat, Indonesia \\ ${ }^{*}$ Corresponding author. Jl. Terusan Jend. Sudirman, 40521, Cimahi, Jawa Barat \\ E-mail: $\quad$ asepikinsugandi@ikipsiliwangi.ac.id $^{1^{*)}}$ \\ pamartin23nrd@gmail.com $^{2)}$ \\ nda112996@ gmail.com ${ }^{3)}$
}

Received 02 October 2020; Received in revised form 09 December 2020; Accepted 20 December 2020

\begin{abstract}
Abstrak
Pada masa covid-19 pembelajaran dilaksanakan secara daring (online), sehingga dibutuhkan beberapa alat belajar berbantuan ICT yang mampu menunjang efektivitas pembelajaran dengan baik yaitu Geogebra. Penelitian ini bertujuan untuk menelaah efektivitas pembelajaran berbasis masalah berbantuan Geogebra terhadap kemampuan penalaran matematis. Metode yang digunakan dalam penelitian ini adalah metode kuasi eksperimen. Populasi penelitian ini adalah seluruh siswa SMK Swasta di kota cimahi, sedangkan sampelnya dipilih tiga kelas yang banyaknya 80 dari satu SMK swasta di kota Cimahi. Instrumen yang digunakan dalam penelitian ini adalah seperangkat tes kemampuan penalaran yang berbentuk soal uraian sebanyak 4 soal. Soal tersebut sudah memenuhi soal yang baik berdasarkan validitas, reliabilitas, daya pembeda dan indeks kesukaran. Berdasarkan hasil perhitungan menggunakan SPSS 18 diperoleh hasil bahwa model berbasis masalah dengan bantuan Geogebra dengan model berbasis masalah maupun biasa memiliki nilai sign. sebesar 0,000, karena nilai sign. $<0,05$, maka dapat disimpulkan bahwa pembelajaran menggunakan model berbasis masalah berbantuan Geogebra lebih efektif dibandingkan model pembelajaran berbasis masalah maupun model biasa ditinjau dari kemampuan penalaran matematis siswa. Dengan demikian penerapan model berbasis masalah berbantuan Geogebra lebih efektif dibandingkan model berbasis masalah maupun konvensional terhadap kemampuan penalaran matematis.
\end{abstract}

Kata kunci: Berbasis masalah 1; Geogebra2; Penalaran matematis 3

\begin{abstract}
During the Covid-19 period, learning was carried out online, so it needed several ICT-assisted learning tools that were able to support the effectiveness of learning well, namely Geogebra. This study aims to examine the effectiveness of Geogebra-aided problem-based learning on abilities. The method used in this study is a quasi-experimental method. The population of this study was all private vocational students in the city of Cimahi, while the sample was selected in three classes with a total of 80 from one private vocational school in the city of Cimahi. The instrument used in this study was a set of reasoning ability tests in the form of 4-item description questions. These questions have fulfilled good questions based on validity, reliability, distinguishing features and difficulty index. Based on the results of calculations using SPSS 18 shows that the problem-based model base on Geogebra with problem-based and ordinary models has a sign value. of 0.000 , because of the sign value. $<0.05$, it can be concluded that learning using a Geogebra-assisted problem-based model is more effective than problem-based learning models and ordinary models in terms of students' mathematical reasoning abilities. Therefore the results are obtained the application of a Geogebra-based problem-based model is more effective than a problem-based or conventional model in terms of mathematical reasoning abilities.
\end{abstract}

Keywords: Problem based 1; Geogebra 2; Mathematical reasoning 3 
DOI: https://doi.org/10.24127/ajpm.v9i4.3133

\section{PENDAHULUAN}

Pada tahun 2020, dunia dilanda cobaan oleh Sang Maha Pencipta terutama negara Indonesia yaitu adanya Virus Covid-19. Hal ini sangat mengkhawatirkan bagi keadaan dan kesehatan manusia, terutama berdampak pada aktivitas pendidikan. Pelaksanaan pendidikan yang semula normal dilakukan langsung dan bertatap muka kini harus terhenti sementara dengan menggunakan berbagai media perantara. Dimana pada masa pandemik ini pembelajaran dilakukan secara daring (online) dengan menggunakan beberapa teknologi informasi sebagai penunjang pelaksanaan pembelajaran seperti aplikasi zoom meeting, google classroom, dan sebagainya, tentu membutuhkan sarana dan prasarana yang memadai, seperti Smartphone, laptop/komputer, ketersediaan kuota/wifi, jaringan internet, dan lainnya. Namun tidak menutup kemungkinan untuk terus melaksanakan pembelajaran dengan lebih baik, sehingga pengetahuan, ketrampilan dan kemampuan serta pola pikir siswa akan terus berkembang dan meningkat, terutama kemampuan bernalar siswa dalam belajar matematika.

Kemampuan Penalaran matematis merupakan suatu jenis hard skill yang penting dalam matematika dan perlu dikuasai siswa. Menurut Ball, Lewis, \& Thamel (Widjaja, Dolk, \& Fauzan, 2010) pentingnya memiliki kemampuan penalaran matematik sebagai fondasi untuk mengkonstruk pengetahuan matematika. Hal ini didukung oleh Ball \& Bass (Brodie, 2010) yang menyatakan bahwa penalaran merupakan kompetensi fundamental matematika yang dibutuhkan untuk memahami konsep. Pentingnya kepemilikan penalaran sesuai KTSP 2006 dan pada kurikulum 2013
(Sumarmo \& Hendriana, 2014) bahwa menggunakan penalaran dalam pola dan sifat, memanipulasi matematika agar dapat membuat generalisasi, menyusun bukti atau mengutarakan dan menjelaskan gagasan atau pernyataan matematika.

Pengertian kemampuan penalaran biasanya dikaitkan dengan proses berpikir siswa untuk menarik kesimpulan yang kebenarannya sudah dibuktikan. Sejalan dengan Sulistianto (2011) menyatakan penalaran merupakan suatu aktivitas, atau proses berpikir dalam menarik kesimpulan atau menggunakan suatu pernyataan yang benar.

Secara garis besar penalaran terbagi dua, yaitu penalaran deduktif dan penalaran induktif (Sumartini, 2015). Penalaran deduktif merupakan penarikan kesimpulan dari hal yang umum menuju hal khusus berdasarkan fakta-fakta yang ada, sedangkan penalaran induktif adalah proses berpikir dengan mengambil keputusan yang bersifat umum atau membuat pernyataan baru dari kasus-kasus yang khusus. Kedua penalaan tersebut perlu dikuasai oleh siswa dalam belajar matematika.

Namun kenyataan di lapangan menyatakan kemampuan penalaran masih rendah, menurut Rosnawati (2013) menyatakan bahwa aspek paling rendah didapat oleh peserta Indonesia terletak pada aspek penalaran yaitu 17\%. Selanjutnya Sulistiawati (2014) menyatakan faktor yang menyebabkan rendahnya kemampuan penalaran matematis siswa adalah pemilihan metode mengajar yang tidak melibatkan siswa secara aktif dalam belajar dan pembelajaran masih berpusat pada guru. Oleh sebab itu diperlukan model belajar yang dapat mengaktifkan siswa pada pembelajaran 
daring (online) sehingga siswa dapat meningkatkan pemahaman dan penalaran matematis.

Model belajar yang efektif untuk menumbuhkan penalaran matematis adalah model belajar berbasis masalah. Menurut Alam (2020) model pembelajaran berbasis masalah signifikan terhadap peningkatan penalaran konsep matematika. Nurhadi (Murdas, 2011) pembelajaran berbasis masalah adalah suatu pembelajaran yang menggunakan masalah dunia nyata sebagai suatu konteks bagi siswa untuk belajar cara berpikir dan menyelesaikan masalah. Simbolon (2019) mengungkapkan bahwa model pembelajaran berbasis masalah dapat mempengaruhi kemampuan penalaran matematis siswa dimana pembelajarannya berpusat pada siswa, dalam belajar siswa tidak sekedar mendengarkan melainkan siswa diberikan suatu masalah, siswa aktif berpikir, berkomunikasi, mencari dan mengolah data, hingga pada kesimpulan. Dengan diterapkan model seperti itu, maka kemampuan penalaran siswa akan terbentuk dan berkembang dengan sendirinya.

Untuk meningkatkan penalaran, matematik siswa selain menggunakan model belajar berbasis masalah juga digunakan software Geogebra. Geogebra adalah salah satu software komputer yang dibuat atau dirancang untuk keperluan di bidang matematika antara lain geometri dan aljabar, Geogebra sudah banyak dikenal di kalangan anak sekolah dan mahasiswa perguruan tinggi sebagai alat untuk dapat membantu siswa dan mahasiswa memecahkan masalah dan juga mendorong untuk memunculkan ide saat melakukan berbagai ekperimen. Menurut Saputro, Prayito, \& Nursyahidah (2015) Geogebra membantu siswa dalam meningkatkan proses eksperimen yang berorientasi masalah, dan penemuan pada konsepkonsep matematika. Siswanto \& Azhar (2018) penggunaan Geogebra merupakan pembelajaran yang efektif untuk mengkreasi lingkungan belajar online interaktif sehingga siswa bisa mengeksplor berbagai konsep matematika, sehingga sangat cocok untuk diterapkan dalam pembelajaran secara daring pada masa covid-19. Dengan demikian menurut Lavisza (Hohenwarter, 2010) Geogebra dapat mendorong proses penemuan dan eksperimentasi dalam belajar matematika.

Berdasarkan uraian permasalahan, dapat disimpulkan bahwa salah satu solusi yang mungkin bisa digunakan untuk meningkatkan kemampuan penalaran siswa adalah dengan menggunakan metode pembelajaran berbasis masalah berbantu Geogebra. Oleh karena itu sesuai dengan kondisi yang sedang maraknya dalam aspek pembelajaran matematika pada masa pandemik, untuk mengetahui apakah solusi ini dapat memberikan dampak positif, maka tujuan dari penelitian ini adalah untuk melihat dan menelaah efektivitas pembelajaran daring berbasis masalah berbantuan Geogebra terhadap kemampuan penalaran matematis di era covid-19.

\section{METODE PENELITIAN}

Metode penelitian ini adalah Kuasi Eksperimen. Penelitian ini dilakukan secara daring melalui zoom meeting. Dalam penelitian ini dibutuhkan tiga kelompok, yaitu kelompok eksperimen I, diberi perlakuan model berbasis masalah dengan bantuan Geogebra, Kelompok eksperimen II yaitu diberi perlakuan pendekatan berbasis masalah dan 
DOI: https://doi.org/10.24127/ajpm.v9i4.3133

kelompok Kontrol yaitu diberi perlakuan pendekatan biasa.

Diawal penelitian ketiga kelompok tersebut diberi tes awal (pretest) untuk mengukur kemampuan awal siswa, setelah pemberian perlakuan, ketiga kelompok diberi tes akhir (posttest) tentang kemampuan penalaran. Adapun desain penelitiannya :

$\begin{array}{ccc}\mathrm{O}_{1} & \mathrm{X}_{1} & \mathrm{O}_{2} \\ \mathrm{O}_{1} & \mathrm{X}_{2} & \mathrm{O}_{2} \\ \mathrm{O}_{1} & & \mathrm{O}_{2}\end{array}$

Keterangan:

$\mathrm{O}_{1}=$ Tes Awal (pre-test)

$\mathrm{O}_{2}=$ Tes Akhir (post-test)

$\mathrm{X} 1$ = Pemberian Model pembelajaran

Berbasis Masalah dengan bantuan Geogebra

$\mathrm{X}_{2}=$ Pemberian Model pembelajaran

Berbasis Masalah

Populasi penelitian ini adalah seluruh siswa di SMK swasta yang berkemampuan sedang di kota Cimahi. Sampelnya adalah siswa kelas XI sebanyak 3 kelas dari salah satu SMK Swasta di Cimahi, yaitu kelas XI Teknik Komputsi Jaringan (TKJ) A,
TKJ B dan Teknik Elektro Industri C, masing-masing sebanyak 24 orang, 27 orang dan 29 orang di SMK TI Pembangunan. Pengambilan sampel dilakukan secara acak kelas dari 16 kelas. Instrumen dalam penelitian adalah tes berupa soal urain sebanyak 4 soal untuk mengukur kemampuan penalaran siswa, dan teknik analisis data dengan menggunakan anova satu jalur.

\section{HASIL DAN PEMBAHASAN}

Deskripsi kemampuan Penalaran matematik merupakan gambaran kualitas kemampuan penalaran secara keseluruhan, berdasarkan jenis model pembelajaran berbasis masalah berbantuan Geogebra, pembelajaran berbasis masalah, dan pembelajaran konvensional. Deskripsi yang dimaksud adalah rata-rata, simpangan baku, dan banyaknya siswa berdasarkan model pembelajaran yang diberikan.

Berdasarkan hasil pengolahan data pada tes awal dan tes akhir didapat hasil sebagaimana tertera pada Tabel 1 .

Tabel 1. Deskripsi kemampuan penalaran.

\begin{tabular}{ccccccccccc}
\hline \multirow{2}{*}{ No } & \multirow{2}{*}{ Tes } & \multicolumn{1}{c}{ BMBG } & \multicolumn{1}{c}{ BM } & \multicolumn{3}{c}{ BS } \\
\cline { 3 - 11 } & & $\bar{x}$ & $\mathrm{~s}$ & $\mathrm{~N}$ & $\bar{x}$ & $\mathrm{~s}$ & $\mathrm{n}$ & $\bar{x}$ & $\mathrm{~S}$ & $\mathrm{~N}$ \\
\hline & Tes awal & 8,33 & 2,10 & 24 & 8,41 & 1,72 & 27 & 8,03 & 1,66 & 29 \\
1 & Tes akhir & 12,33 & 2,10 & 24 & 10,15 & 1,51 & 27 & 8,11 & 1,51 & 29 \\
\hline
\end{tabular}

Keterangan:

Skor maksimum 16

\begin{tabular}{|c|c|c|c|}
\hline BMBG & $=$ & $\begin{array}{l}\text { Pembelajaran } \\
\text { Masalah } \\
\text { Geogebra }\end{array}$ & $\begin{array}{r}\text { Berbasis } \\
\text { Berbantuan }\end{array}$ \\
\hline $\mathrm{BM}$ & $=$ & $\begin{array}{l}\text { Pembelajaran } \\
\text { Masalah }\end{array}$ & Berbasis \\
\hline BS & $=$ & Pembelajaran & n Biasa \\
\hline
\end{tabular}

Tabel 1 dapat dideskripsikan bahwa pada pembelajaran berbasis masalah berbantuan Geogebra memiliki nilai rata-rata hasil tes akhir siswa lebih besar dar pada tes awal siswa dengan selisih rata-rata 4, sama halnya pada pembelajaran berbasis masalah rata-rata hasil akhir siswa lebih besar daripada tes awal dengan selisih 1,74, dan pada pembelajaran biasa rata-rata hasil tes akhir siswa lebih besar pula daripada tes awal namun dengan selisih lebih kecil dibandingkan pembelajaran berbasis masalah dengan selisih 0,08. Dengan demikian peningkatan terbesar dari hasil 
tes siswa ialah pada pembelajaran berbasis masalah berbantuan Geogebra.

Untuk selanjutnya dilakukan uji normalitas terhadap nilai tes awal dan tes akhir. Berdasarkan hasil pengolahan data, dapat disajikan pada Tabel 2.

Tabel 2. Hasil uji normalitas.

\begin{tabular}{ccccc}
\hline \multirow{3}{*}{ Tes } & \multicolumn{3}{c}{ Kolmogorov-Smirnov } \\
\cline { 2 - 5 } Awal & Kelas & Stat. & Df & Sign. \\
\hline \multirow{4}{*}{ Akhir } & BM & 0,138 & 24 & 0,200 \\
& BS & 0,143 & 27 & 0,168 \\
& BMB & 0,147 & 29 & 0,108 \\
& BS & 0,158 & 24 & 0,200 \\
& 0,158 & 29 & 0,082 \\
\hline
\end{tabular}

Berdasarkan pada Tabel 2 didapat data untuk pre tes, nilai sign untuk kelas BMBG, BM dan BS masing-masing sebesar 0,200; 0,168 dan 0,108, karena ketiga kelas memiliki nilai sign. > 0,05, maka disimpulkan data tes awal berdistribusi normal sedangkan untuk ujian akhir didapat nilai sign. untuk kelas BMBG, BM dan BS masing- masing sebesar 0,200; 0,082 dan 0,061, karena ketiga kelas memiliki nilai sign. $>0,05$, maka dapat disimpulkan bahwa data tes akhir berdistribusi normal.

Selanjutnya dilakukan uji homogenitas dengan menggunakan uji Lavene., dari hasil pengolahan data didapat hasil seperti pada Tabel 3 .

Tabel 3. Hasil uji homogenitas.

\begin{tabular}{ccccc}
\hline Tes & Lavene & df1 & df2 & Sign. \\
\hline Awal & 0,551 & 2 & 77 & 0,579 \\
Akhir & 1,193 & 2 & 77 & 0,309 \\
\hline
\end{tabular}

Dari Tabel 3 didapat nilai sign. sebesar 0,579 dan untuk tes akhir didapat nilai sign. sebesar 0,309 , karena kedua nilai sign. > 0,05 disimpulkan varians untuk tes awal dan tes akhir homogen. Berdasarkan hasil pengolahan data didapat bahwa data berdistribusi normal dan homogen, maka selanjutnya dilakukan uji anova satu jalur. Berdasarkan hasil pengolahan data pada tes awal dan tes akhir didapat hasil sebagaimana tertera pada Tabel 4.

Tabel 4. Rangkuman hasil uji ANOVA satu jalur.

\begin{tabular}{ccccccc}
\hline Tes & Nilai & Sum of Squares & Df & $\begin{array}{c}\text { Mean } \\
\text { Squares }\end{array}$ & $\boldsymbol{F}$ & Sig. \\
\hline \multirow{2}{*}{ Awal } & Between & 2,183 & 2 & 1,091 & 0,330 & 0,720 \\
& Within & 254,817 & 77 & 3,309 & & \\
Akhir & Between & 175,002 & 2 & 87,501 & 29,952 & 0,000 \\
& Within & 224,948 & 77 & 2,921 & & \\
& Total & 399,950 & 79 & & & \\
\hline
\end{tabular}

Berdasarkan hasil uji anova satu jalur untuk tes awal didapat nilai sign sebesar sebesar 0,702. Karena nilai sign. > 0,05 maka disimpulkan bahwa tidak terdapat perbedaan kemampuan awal penalaran matematis antara siswa yang diajar dengan model berbasis masalah berbantuan geogebra, yang diajar berbasis masalah maupun pembelajaran biasa. Untuk hasil tes akhir didapat nilai sign. sebesar 0,000 , karena nilai sign $<0,05$ maka disimpulkan bahwa terdapat perbedaan kemampuan penalaran matematis siswa antara yang pembelajarannya menggunakan model berbasis masalah dengan bantuan geogebra dengan pembelajaran berbasis masalah dan pembelajaran biasa. Untuk mengetahui pasangan mana yang berbeda selanjutnya digunakan uji Scheffe, maka didapat seperti pada Tabel 5. 
DOI: https://doi.org/10.24127/ajpm.v9i4.3133

Tabel 5. Rangkuman hasil uji Scheffe

\begin{tabular}{cccc}
\hline $\begin{array}{c}\text { Kelas } \\
(\mathrm{I})\end{array}$ & $\begin{array}{c}\text { Kelas } \\
(\mathrm{II})\end{array}$ & $\begin{array}{c}\text { Mean- } \\
\text { difference }\end{array}$ & Sign. \\
\hline BMBG & BM & 2,185 & 0,000 \\
& BS & 3,299 & 0,000 \\
BM & BS & 1,458 & 0,008 \\
\hline
\end{tabular}

Berdasarkan Tabel 5 didapat untuk pasangan model berbasis masalah dengan bantuan geogebra dengan model berbasis masalah maupun biasa memiliki nilai sign. Sebesar 0,000, karena nilai sign. $<0,05$, maka dapat disimpulkan bahwa pembelajaran menggunakan model berbasis masalah berbantuan geogebra lebih efektif dibandingkan model pembelajaran berbasis masalah maupun model biasa ditinjau kemampuan penalaran matematis siswa, kemudian untuk pasangan pembelajaran berbasis masalah dengan pembelajaran biasa memiliki nilai sign. Sebesar 0,008, karena nilai sign. $<0,05$, maka dapat disimpulkan bahwa pembelajaran berbasis maslaah lebih efektif daripada pembelajaran biasa ditinjau kemampuan penalaran matematis.

Berdasarkan hasil yang telah diuraikan di atas maka dapat disimpulkan bahwa penerapan model berbasis masalah berbantuan geogebra lebih efektif dari pada model berbasis masalah maupun pembelajaran biasa. demikian juga model berbasis masalah lebih efektif daripada pembelajaran biasa. Hal ini sejalan dengan hasil penelitian (Asmara, 2016), (Ramadhani, 2016) menyatakan penggunaan model berbasis masalah berbantuan geogebra lebih efektif dibandingkan model biasa ditinjau dari kemampuan berpikir matematis tingkat tinggi, Asmara menelti tentang aspek pemecahan masalah pada siswa SD, sedangkan Ramdhani meneliti pada aspek pemecahan masalah pada siswa SMA
Selanjutnya penelitian ini juga sesuai penelitian (Sumartini, 2016), (Jumaisyaroh, Napitupulu, \& Hasratuddin, 2015) menyatakan penerapan model berbasis masalah lebih efektif dari pada model langsung ditinjau dari aspek berpikir tingkat tinggi, Sumartini (2015) meneliti pada aspek penalaran dan pemecahan masalah pada siswa SMK, sedangkan Jumaisyaroh (2015) meneliti pada aspek berpikir kritis pada siswa SMP. Adapun hasil tes siswa dalam menyelesaikan soal geometri tanpa menggunakan software geogebra, seperti Gambar 1 dan Gambar 2 di bawah ini.

\section{Soal 1.}

Diketahui prisma tegak segiempat ABCD.EFGH memiliki panjang rusuk $A B=B C=2 \mathrm{~cm} \quad$ dan $\quad C G=$ $4 \mathrm{~cm}$. Cosinus sudut yang dibentuk oleh bidang $B D G$ dan $B D E$ adalah ....

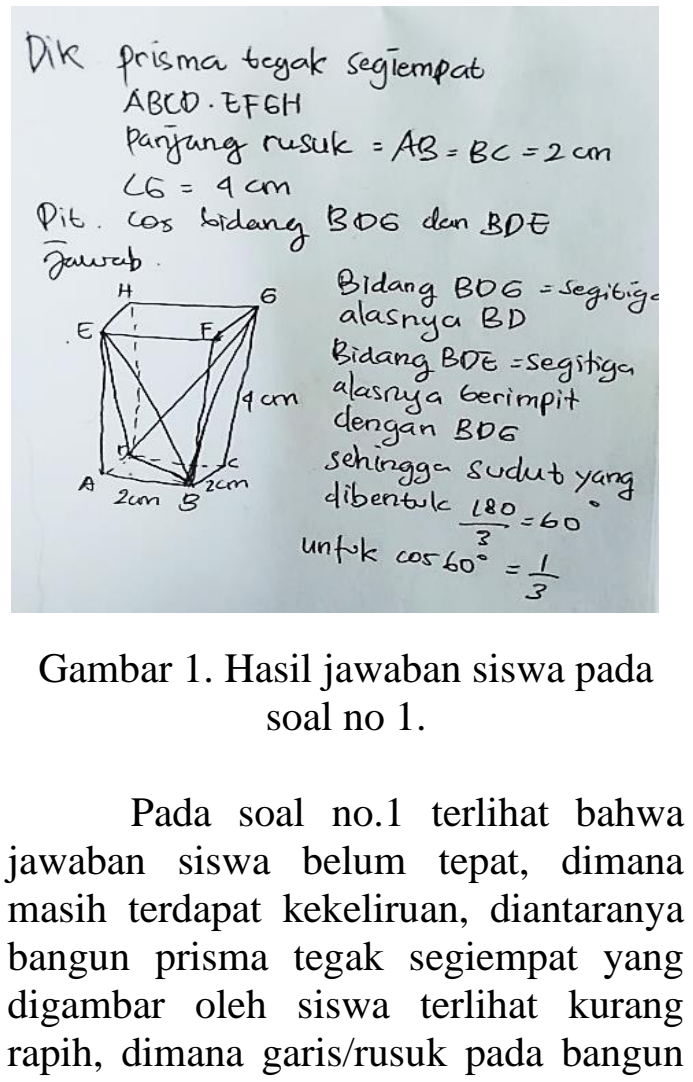


tersebut masih terlihat sedikit tidak lurus, cara yang digunakan siswa dalam menyelesaikan masalah belum sesuai dengan prosedur penyelesaian berbasis masalah (terlalu singkat), siswa hanya mengkonstruksikan 1 gambar untuk menyelesaikan prosedur, siswa keliru dalam menentukan nilai $\cos 60^{\circ}$ sehingga jawaban siswa belum tepat.

\section{Soal 2.}

Sebuah kubus ABCD.EFGH memiliki panjang rusuk $2 \mathrm{~cm}$. Tentukan nilai tan sudut yang dibentuk oleh bidang BDE dan bidang BDG!

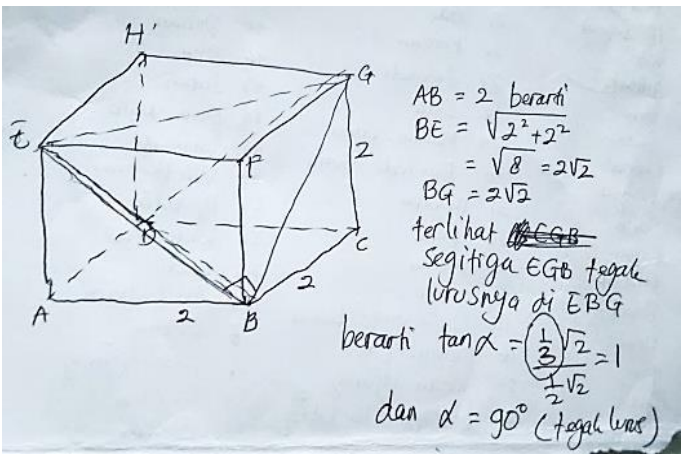

Gambar 2. Hasil jawaban siswa pada soal no 2 .

Pada soal no.2 terlihat bahwa jawaban siswa masih kurang tepat, dalam menyelesaikannya masih terdapat kekeliruan, dimana untuk $\tan \alpha$ tersebut ialah $2 \sqrt{2}$ bukan $\frac{1}{3} \sqrt{2}$, dan gambar kubus yang dilukiskan oleh siswa kurang rapih.

Sedangkan hasil tes siswa dalam menyelesaikan soal berbasis masalah berbantuan geogebra dapat disajikan pada Gambar 3.

\section{Soal 1.}

Diketahui prisma tegak segiempat ABCD.EFGH memiliki panjang rusuk $A B=B C=2 \mathrm{~cm} \quad$ dan $\quad C G=$ $4 \mathrm{~cm}$.Cosinus sudut yang dibentuk oleh bidang $B D G$ dan $B D E$ adalah ...

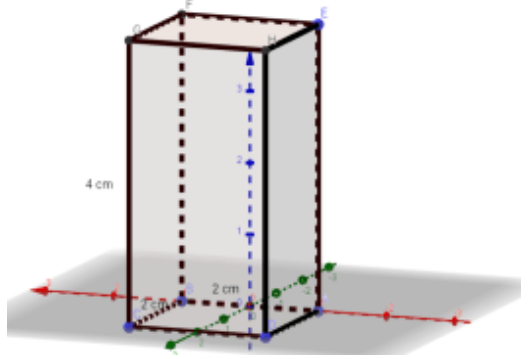

Gambar 3. Membuat Prisma tegak Segiempat

Gambar 3 menjelaskan soal awal yang diketahui adalah membuat prisma tegak segiempat ABCD.EFGH yang memiliki ukuran $\mathrm{AB}=\mathrm{BC}=2 \mathrm{~cm}$ dan $\mathrm{CG}=4 \mathrm{~cm}$, sehingga membentuk gambar balok dengan alas persegi. Pada tahap ini, siswa diberikan kesempatan untuk mengamati soal yang diintreprestasikan gambar dalam Geogebra. Berikutnya, siswa diberikan waktu untuk membuat gambar bidang BDG terlebih dahulu seperti Gambar 4.

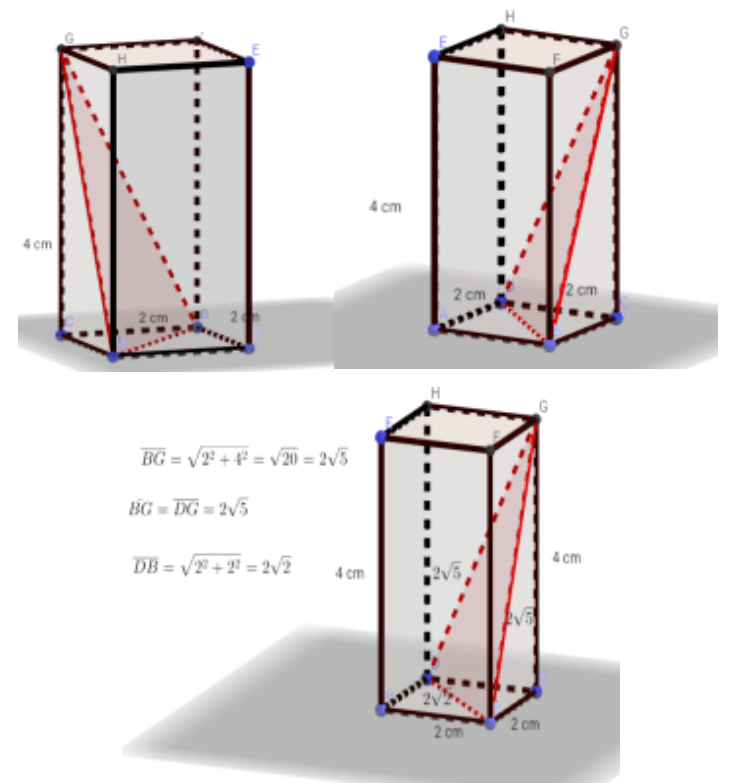

Gambar 4. Membuat Bidang BDG

Gambar 4. menjelaskan siswa membuat gambar dari tiga titik yaitu BDG, sehingga siswa mendapatkan gambar segitiga BDG. Pada tahap ini siswa mengamati bentuk segitiga 
dengan menggunakan Rotate $3 D$ Graphics View, dengan tujuan melihat bahwa segitiga berada di dalam balok sambil menentukan hasil dari sisi-sisi segitiga sehingga disimpulkan bahwa segitiga BDG adalah segitiga sama kaki dengan panjang $\mathrm{BG}$ sama dengan panjang DG dengan menentukan nilai panjang menggunakan rumus phytagoras yaitu $2 \sqrt{5}$, sedangkan untuk nilai panjang panjang BD dengan cara yang sama yaitu menggunakan rumus phytagoras yaitu $2 \sqrt{2}$. Dan selanjutnya menggambar BDE sesuai dengan soal tersebut, seperti Gambar 5.

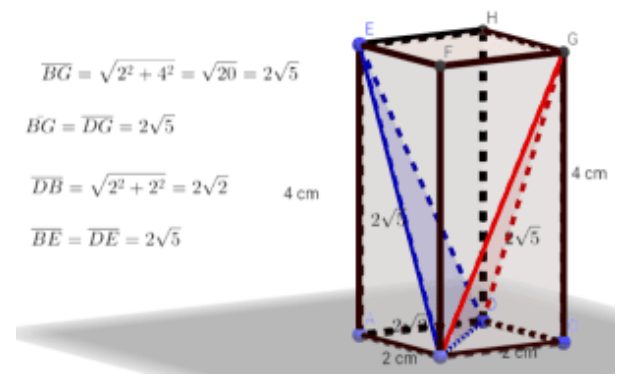

Gambar 5. Membuat bidang BDE

Gambar 5 menjelaskan pada tahap ini siswa sudah memahami gambar segitiga $\mathrm{BDE}$ dan menyebutkan sisi-sisi segitiga BDE, yang disimpulakan bahwa kedua segitiga tersebut adalah kongruen yaitu memiliki panjang sisisisi dari keduanya sama dimana panjang BE dan panjang DE sama dengan $2 \sqrt{5}$ dan BD sama dengan

$2 \sqrt{2}$. Selanjutnya, tampak bahwa kedua segitiga saling mengapit yang tentunya membentuk sudut. Dari pengertian sudut dijelaskan dengan menggunakan definisi yaitu jika ada dua sinar yang terletak pada satu titik pusat yang berarti membuat sinar yang terletak pada bidang BDE dan sinar yang terletak pada bidang BDG. Namun, agar tidak terjadi kekeliruan bahwa segitiga BDE harus terletak pada bidang segiempat atau ketiga titik harus terletak pada segiempat demikian juga untuk segitiga BDG seperti Gambar 6.

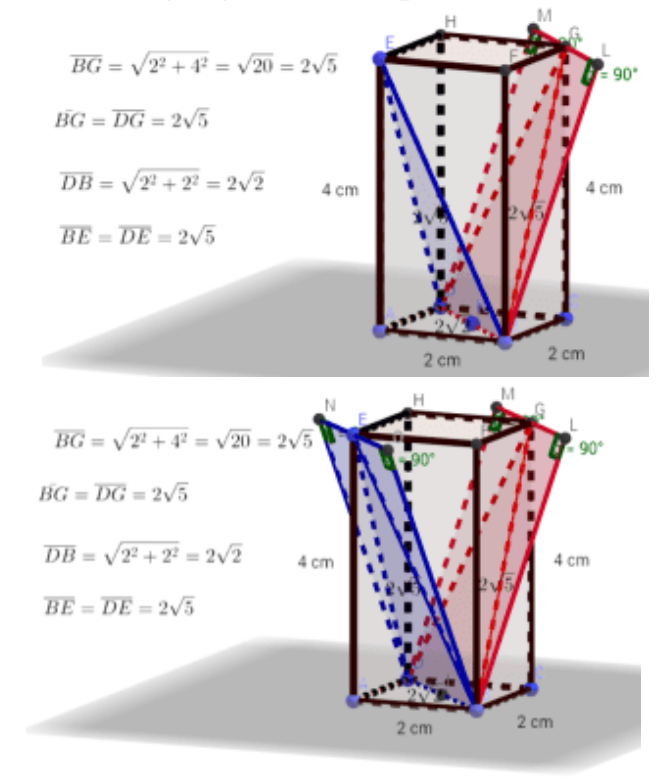

Gambar 6. Membuat Bidang Segiempat untuk Bidang BDE dan BDG

Gambar 6 menjelaskan perlu adanya gambaran persegi panjang yang meletakan kedua segitiga yaitu BDE dan BDG sehingga, siswa melihat tampak ada dua papan yang saling mengapit yaitu papan BDNO yang meletakan segitiga BDE dan BDML yang meletakan segitiga BDG. Pada tahap ini siswa diberikan kesempatan untuk mengeksplor menggunakan Rotate 3D Graphics View, sehingga menemukan satu titik sebagai sumber dan dua sinar yang dimaksud untuk mendapatkan sudut, seperti Gambar 7.

Gambar 7 menjelaskan kesimpulan hasil dari sinar PG dan sinar $\mathrm{PE}$ dengan pusat sinar pada titik $\mathrm{P}$, lalu siswa mengamati dan membuat langkah-langkah untuk menentukan sudut antara bidang BDE dan bidang BDG dengan membuat sketsa segitiga PGE dan menentukan sisi-sisi segitiga tersebut. dari informasi tersebut memudahkan siswa mencari sudut 
dengan menggunakan aturan cosinus dan didapatkan hasil akhir dari jawaban siswa adalah $\cos \measuredangle E P G=\frac{7}{9}$. Dengan demikian jawaban dan konsep penyelesaian dari siswa bisa dikonstruksi dengan jelas, dan hasil jawaban akhirnya tepat.

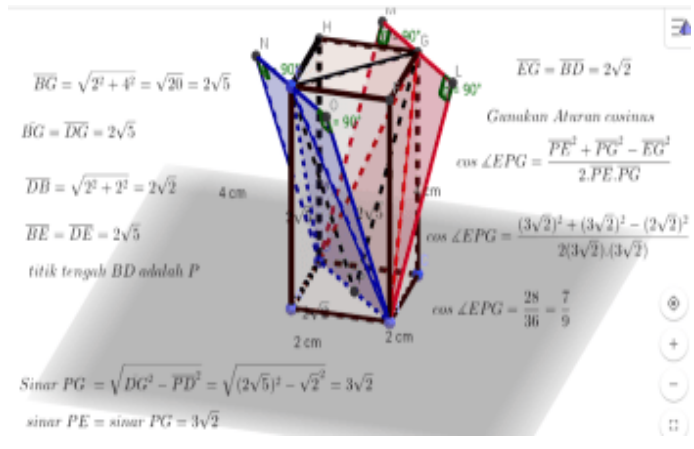

Gambar 7. Sudut Bidang BDE dan BDG

\section{Soal 2.}

Sebuah kubus ABCD.EFGH memiliki panjang rusuk $2 \mathrm{~cm}$. Tentukan nilai tan sudut yang dibentuk oleh bidang BDE dan bidang BDG!

Dik. kubus ABCD.EFGH panjang $A B=B C=C G=2 \mathrm{~cm}$.

Dit. tan sudut yang dibentuk oleh bidang BDE dan BDG?

Setelah siwa menuliskan apa yang diketahui dan apa yang ditanykan, lalu siswa mengkonstruksi bangun kubus dengan melukiskan bidang BDE dan BDG dengan menggunakan geogebra, seperti Gambar 8.
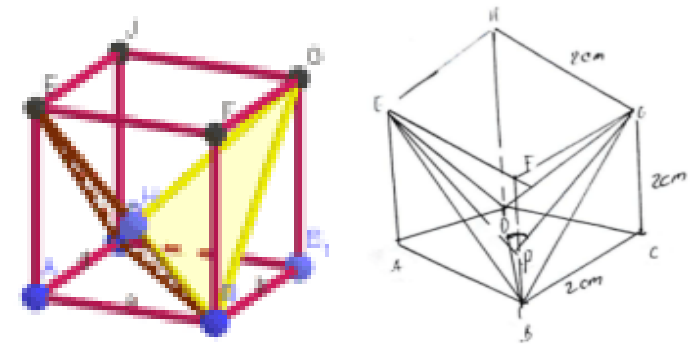

Gambar 8. Membuat kubus ABCD. EFGH dengan bidang BDE dan BDG
Pada gambar 8 terlihat bahwa tampilan kubus rapih sehingga dengan geogebra siswa mudah untuk melukiskan berbagai bidang pada bangun ruang, dengan mengkonstruksikan konsep melalui geogebra siswa dapat dengan mudah menyusun langkah-langkah penyelesaian masalah secara terstruktur sesuai dengan kemampuannya dan bisa mengembangkan gagasan dengan luas dan logis, hingga menemukan jawaban yang tepat.

Berdasarkan pengamatan, maka dengan melihat hasil jawaban dari siswa dapat dinyatakan bahwa model berbasis masalah berbantuan Geogebra lebih efektif daripada model berbasis masalah maupun model biasa. Penyajian materi dalam bentuk bahan ajar yang disajikan dalam bentuk masalah memungkinkan siswa mendapatkan peluang dalam mengembangkan konsep, prosedur, dan prinsip dalam matematika, ini sesuai dengan karakteristik penalaran yang memberikan penjelasan fakta, model, sifat, hubungan atau pola; dan dapat menggunakan pola hubungan untuk mengkaji situasi, dan membangun dugaan, sehingga model berbasis masalah berbantuan Geogebra dapat meningkatkan penalaran siswa. Hal ini sejalan dengan pendapat Usta (Cetin, Mirasyedioglu, \& Cakiroglu, 2019), menemukan bahwa metode berbasis masalah berbantuan Geogebra memiliki efek positif pada siswa dalam hal meningkatkan keterampilan berpikir tingkat tinggi seperti pemecahan masalah, asosiasi, dan deduktif. penalaran, dan hasil lainnya seperti keterampilan komunikasi matematika siswa. Selain itu, dari pengamatan, juga ditemukan bahwa pendalaman materi dalam bentuk diskusi dan penggunaan aplikasi Geogebra akan memudahkan siswa untuk berpikir karena 
menggunakan Geogebra dapat menggambar geometri dengan teliti dan dapat menunjukkan propertinya. yang berlaku untuk geometri. Ini sejalan dengan hasil (Takači, Stankov, \& Milanovic, 2015) berdasarkan wawancara dengan siswa memperoleh hasil bahwa geogebra memudahkan siswa untuk membahas topik, memungkinkan mereka untuk berkomunikasi, bekerja sama dan mendukung pemahaman belajar dan mendapatkan umpan balik cepat. Lebih lanjut Arbain dan Shukor (Cetin et al., 2019) melaporkan bahwa aplikasi Geogebra memiliki efek signifikan dan positif pada siswa, dan meningkatkan motivasi siswa, kepercayaan diri, kemauan untuk belajar, dan keterampilan berpikir, matematis tingkat tinggi, yang salah satunya kemampuan penalaran matematis.

Dengan pembelajaran menggunakan software Geogebra siswa dituntut agar menyelesaikan dapat menyelesaikan masalah dengan berbagai metode berbeda sehingga hal ini mengakibatkan meningkatkanya kemampuan berpikir kreatif. Hal ini sejalan pendapat (Siswanto \& Kusumah, 2017) menyatakan alternatif pembelajaran yang dapat mendorong peningkatan kreativitas mahasiswa adalah pembelajaran menggunakan media pembelajaran yang salah satunya Geogebra. Dengan meningkatkanya kemampuan penalaran akan meningkatkan juga kemampuan pemecahan masalah, karena berpikir kreatif berpengaruh positif terhadap pemecahan masalah. Hal ini sesuai dengan pendapat (Wahyuddin, 2016) yang menyatakan bahwa terdapat hubungan positif yang signifikan antara kreativitas dengan pemecahan masalah, artinya penalaran merupakan tulang punggung tugas memecahkan masalah.
Jadi dengan demikian jika kemampuan pemecahan masalah meningkat maka kemampuan penalaran juga meningkat. Hal-hal tersebut tidak terdapat pada model berbasis masalah dan pembelajaran biasa, namun model berbasis masalah berbantuan Geogebra lebih efektif dari model berbasis masalah maupun model biasa ditinjau dari kemampuan penalaran matematis siswa dalam pembelajaran secara daring.

\section{KESIMPULAN DAN SARAN}

Dari hasil penelitian dan pembahasan dapat disimpulkan bahwa Pembelajaran menggunakan model berbasis masalah berbantuan Geogebra pada pembelajaran daring lebih efektif daripada menggunakan model berbasis masalah maupun pembelajaran biasa terhadap kemampuan penalaran matematis siswa SMK, begitu juga pembelajaran berbasis masalah lebih efektif daripada pembelajaran biasa terhadap aspek penalaran matematis siswa SMK.

Pembelajaran berbasis masalah berbantuan Geogebra dapat diterapkan dalam pembelajaran matematika khususnya topik-topik terpilih dan esensial dalam matematika yang diterapkan pada pembelajaran secara daring. Bagi peneliti selanjutnya pembelajaran berbasis masalah dengan bantuan Geogebra dapat diterapkan dalam upaya mengembangkan kemampuan berpikir matematis tingkat tinggi lainnya dengan populasi yang berbeda.

\section{DAFTAR PUSTAKA}
Alam, P. P. (2020). Model Pembelajaran Berbasis Masalah dan Pemahaman Konsep Matematika pada Peserta Didik Kelas X MAN 1 Baraka Enrekang. 
DOI: https://doi.org/10.24127/ajpm.v9i4.3133

Diferensial Jurnal Pendidikan Matematika, 1(2), 16-22.

Asmara, A. S. (2016). Peningkatan Kemampuan Pemecahan Masalah dan Disposisi Matematis Siswa SMK dengan Pembelajaran Berbasis Masalah Berbantuan Multimedia Interactive. Jurnal Sekolah Dasar, 1(1).

Brodie, K. (2010). Teaching Mathematical Reasoning in Secondary School Classrooms. Springer Science \& Business Media., 775.

Cetin, Y., Mirasyedioglu, S., \& Cakiroglu, E. (2019). An Inquiry into the Underlying Reasons for the Impact of Technology Enhanced Problem-Based Learning Activities on Students' Attitudes and Achievement. Eurasian Journal of Educational Research, 7(9), 191-208.

Hendriana, H., Rohaeti, E. E., \& Sumarmo, U. (2017). Hard Skills dan Soft Skills Matematik Siswa (I). Bandung: Refika Aditama.

Hohenwarter, M., et al. (2010). Teaching and Learning Calculus with Free Dynamic Mathematics Software GeoGebra. [Online]. Tersedia;Http://Www/Publications. Uni.Lu/Record/2718/Files/ICME1 1-TSG16.Pdf. [8 Desember 2020]. Jumaisyaroh, T., Napitupulu, E. E., \& Hasratuddin, H. (2015). Peningkatan Kemampuan Berpikir Kritis Matematis dan Kemandirian Belajar Siswa SMP melalui Pembelajaran Berbasis Masalah. Kreano, Jurnal Matematika Kreatif-Inovatif, 5(2), 157-169.

Murdas, M. (2011). Meningkatkan Hasil Belajar Matematika melalui Model Pembelajaran Berbasis Masalah pada Peserta Didik Kelas VIII.A MTs di Lero Kec.Suppa
Kab.Pinrang. $\quad$ Skripsi: Tidak Diterbitkan.

Ramadhani, R. (2016). Peningkatan Kemampuan Pemecahan Masalah Matematika Siswa SMA Melalui Model Problem Based Learning Berbantuan Software Geogebra. Jurnal Ilmiah INTEGRITAS, 2(1).

Rosnawati. (2013). Kemampuan Penalaran Matematika Siswa SMP Indonesia pada TIMSS 2011. Prosiding Seminar Nasional Penelitian, Pendidikan Dan Penerapan. Yogyakarta: Universitas Negeri Yogyakarta.

Saputro, B. A., Prayito, M., \& Nursyahidah, F. (2015). Media Pembelajaran Geometri Menggunakan Pendekatan Pendidikan Matematika Realistik Berbasis GeoGebra. Kreano, Jurnal Matematika KreatifInovatif, 6(1), 34-39.

Simbolon, E. F. (2019). Pengaruh Model Pembelajaran Problem Based Learning (PBL) terhadap Kemampuan Penalaran Matematis Siswa. Universitas Negeri Medan, Unimed Press. 1-9.

Siswanto, R. D., \& Azhar, E. (2018). Workshop Penerapan Software Geogebra sebagai Media Pembelajaran Matematika untuk Guru Sekolah Dasar Kelurahan Pademangan Barat. Jurnal Publikasi Pendidikan, 8(3), 224228.

Siswanto, R. D., \& Kusumah, Y. S. (2017). Peningkatan Kemampuan Geometri Spasial Siswa SMP Melalui Pembelajaran Inkuiri Terbimbing Berbantuan GeoGebra. JPPM (Jurnal Penelitian Dan Pembelajaran Matematika), 10(1).

Sulistianto, J. (2011). Keefektifan Model Pembelajaran Kontekstual dengan Pendekatan Open-Ended dalam 
DOI: https://doi.org/10.24127/ajpm.v9i4.3133

Aspek Penalaran dan Pemecahan Masalah Pada Materi Segitiga di Kelas VII SMP. Majalah Ilmiah Pendidikan Dasar, 1(1).

Sumarmo, U., \& Hendriana, H. (2014). Penilaian dan Pembelajaran Matematika. Bandung, Indonesia: Refika Aditama.

Sumartini, T. S. (2015). Peningkatan kemampuan penalaran matematis siswa melalui pembelajaran berbasis masalah. Mosharafa: Jurnal Pendidikan Matematika, 4(1), 1-10.

Sumartini, T. S. (2016). Peningkatan kemampuan pemecahan masalah matematis siswa melalui pembelajaran berbasis masalah. Mosharafa: Jurnal Pendidikan Matematika, 5(2), 148-158.
Takači, D., Stankov, G., \& Milanovic, I. (2015). Efficiency of learning environment using GeoGebra when calculus contents are learned in collaborative groups. Computers \& Education, 8(2), 421-431.

Wahyuddin, M. (2016). Pengaruh Metakognisi, Motivasi Belajar, dan Kreativitas Belajar Terhadap Kemampuan Pemecahan Masalah Siswa Kelas VIII SMP Negeri 2 Sabbangparu Kabupaten Wajo. Jurnal Inovasi Pendidikan Matematika, 4(1), 72-82.

Widjaja, W., Dolk, M., \& Fauzan, A. (2010). The role of contexts and teacher's questioning to enhance students' thinking. Journal of Science and Mathematics Education in Southeast Asia, 33(2), 168-186. 